\title{
The Effect of Green Human Resource Management on Environmental Performance in Small Tourism Enterprises: Mediating Role of Pro-Environmental Behaviors
}

\author{
Ibrahim A. Elshaer ${ }^{1,2, * \mathbb{C}}$, Abu Elnasr E. Sobaih ${ }^{1,3} \mathbb{C}^{\mathbb{C}}$, Meqbel Aliedan ${ }^{1}$ and Alaa M. S. Azazz ${ }^{4,5}$ \\ 1 Management Department, College of Business Administration, King Faisal University, \\ Al-Hassa 31982, Saudi Arabia; asobaih@kfu.edu.sa (A.E.E.S.); maliedan@kfu.edu.sa (M.A.) \\ 2 Department of Hotel Studies, Faculty of Tourism and Hotel Management, Suez Canal University, \\ Ismailia 41522, Egypt \\ 3 Faculty of Tourism and Hotel Management, Helwan University, Cairo 12612, Egypt \\ 4 Social Studies Department, College of Art, King Faisal University, Al-Hassa 31982, Saudi Arabia; \\ aazazz@kfu.edu.sa \\ 5 Department of Tourism Studies, Faculty of Tourism and Hotel Management, Suez Canal University, \\ Ismailia 41522, Egypt \\ * Correspondence: ielshaer@kfu.edu.sa
}

Citation: Elshaer, I.A.; Sobaih, A.E.E.; Aliedan, M.; Azazz, A.M.S. The Effect of Green Human Resource Management on Environmental Performance in Small Tourism Enterprises: Mediating Role of Pro-Environmental Behaviors. Sustainability 2021, 13, 1956. https:// doi.org/10.3390/su13041956

Academic Editor: Carla Curado

Received: 14 January 2021

Accepted: 6 February 2021

Published: 11 February 2021

Publisher's Note: MDPI stays neutral with regard to jurisdictional claims in published maps and institutional affiliations.

Copyright: (C) 2021 by the authors Licensee MDPI, Basel, Switzerland. This article is an open access article distributed under the terms and conditions of the Creative Commons Attribution (CC BY) license (https:// creativecommons.org/licenses/by/ $4.0 /)$.

\begin{abstract}
Research on the interrelationship between green human resource management (GHRM), employee pro-environmental behaviors, and environmental performance remains very limited, especially in relation to small tourism enterprises. This research bridges a knowledge gap and examines the direct effect of GHRM on environmental performance in small tourism enterprises and the indirect effect through employee pro-environmental behaviors. For this purpose, a quantitative research approach was adopted using a pre-tested instrument. A questionnaire was handed to employees in small hotels and travel agencies in Greater Cairo, Egypt. The results of structural equation modeling (SEM) showed a positive significant effect of GHRM on both types of proenvironmental behaviors (tasked-related and proactive). However, the results, surprisingly, showed no significant direct effect of GHRM on environmental performance. Notwithstanding, there was an indirect, positive, and significant effect of GHRM on environmental performance through taskedrelated and proactive pro-environmental behaviors. This reflects the value and vital role of employee pro-environmental behaviors in the relationship between GHRM and environmental performance in small tourism enterprises. The research provided various implications for tourism scholars and practitioners, especially those related to small tourism enterprises. Research limitations and opportunities for further research are also discussed.
\end{abstract}

Keywords: green human resource management (GHRM); environmental performance; pro-environmental behavior; task-related pro-environmental behavior; proactive pro-environmental behavior; small tourism enterprises

\section{Introduction}

Sustainability has gained greater attention from policymakers, scholars, and industry practitioners in recent decades, especially after issuing the United Nations sustainable development goals (UNSDGs). In this context, organizations have realized that sustaining their business is dependent on the preservation of natural resources or the environment. It is well documented that organizations' slovenliness of the natural environment will definitely disturb not only environmental sustainability but also their financial sustainability [1] Hence, organizations have recognized the value of integrating sustainability of environmental, social, and financial dimensions into their business model and operations [2]. As a result, there has been a growing interest of scholars in "greening" organizations in recent years [3]. This includes the emergence of green human resource management (GHRM) to 
integrate environmental management into HRM functions [4]. GHRM was found to play a crucial role in developing a culture of sustainability in organizations [5].

GHRM could be defined as the implementation of HRM functions that positively affect employee pro-environmental behaviors, and ultimately support proper environmental performance of the organizations $[3,6]$. It integrates the environmental management in all HRM practices, starting from recruitment and selection through training and development till the management of employee performance [4]. Pro-environmental behavior is a form of workplace behavior that includes all actions undertaken by employees, whether formal duties or voluntary initiatives, to conserve the environment, e.g., saving water and electricity, recycling paper, and double-sided print [3]. These actions are more likely to positively affect environmental performance in the organizations $[3,6]$. Research has also confirmed that environmental performance depends on sustaining employees' abilities, capabilities, and motivation, who are the basis of the environmental management system [5].

Recent research [3,5-7] has shown a relationship between GHRM, employees' green or pro-environmental behaviors, and environmental performance. However, research on the interrelationship between these variables in the tourism context remains very limited [5]. Research on GHRM, green or pro-environmental behavior, and environmental performance often focuses on large businesses with limited studies addressing these issues on small businesses [8]. This is especially true for small tourism enterprises [7]. Despite small tourism enterprises encompassing a major proportion of tourism industry globally, research on GHRM, eco-friendly, green or pro-environmental behavior, and environmental performance remains very limited, and few studies have addressed these issues in the small tourism context [7]. Hence, this research is an attempt to bridge this gap in knowledge regarding the interrelationship between GHRM, employee pro-environmental behaviors, and environmental performance in small tourism enterprises.

The results of research on large businesses cannot simply be applied to small tourism enterprises, e.g., small hotels and travel agencies, since they have different characteristics from large businesses, such as deficiencies in HRM support [7], which could affect the environmental management system. Hence, the role of leadership is crucial to ensure the provision of GHRM that positively affects environmental performance [8]. Recent research on GHRM and environmental performance in small enterprises in general [8] and on small tourism enterprises in particular [7] has identified the need for further research on GHRM in small businesses to enhance their environmental performance, i.e., the sustainability of these businesses and their contribution to the industry as well as the overall economy.

The purpose of the current research is to examine the interrelationship between GHRM and environmental performance through employee pro-environmental behaviors in small tourism enterprises. More specifically, this research has two main objectives. First, the research examines the direct effect of GHRM on pro-environmental behavior, whether tasked-related or proactive behaviors, and on environmental performance in small tourism enterprises in Egypt. Second, it also investigates the mediating role of employee proenvironmental behaviors, both tasked-related and proactive, in the relationship between GHRM and environmental performance of small tourism enterprises. The research draws on GHRM theory [4] and resource-based view theory [8], adopting a comprehensive framework to examine the interrelationship between GHRM and environmental performance through both types of employee pro-environmental behaviors, which have not been studied before in small tourism enterprises. The research establishes proper implications for tourism scholars and practitioners, especially those of small tourism enterprises in Egypt and other countries of the same context, of how to achieve appropriate sustainability and environmental performance through GHRM and employee pro-environmental behaviors.

\section{Review of Literature}

\subsection{GHRM and Pro-Environmental Behaviors}

GHRM incorporates environmental management objectives into HRM practices, such as recruitment and selection, compensation and incentives, training and development, 
and performance appraisal [4]. GHRM is linked with employees' pro-environmental behaviors and the environmental strategy of the organization [3,9]. Pro-environmental behaviors are workplace behaviors that are intended for positive actions towards the environment, such as conserving water and saving energy. Pro-environmental behaviors include two different types of behaviors: task-related pro-environmental behavior and proactive pro-environmental behavior [6]. Task-related pro-environmental behavior comprises performing the formal activities or tasks mentioned in the job description in an environmentally friendly way [10]. On the other hand, proactive pro-environmental behavior is a voluntary behavior, which contains personal initiatives and a self-starting approach to behave in an eco-friendly way [6]. Hence, both types of pro-environmental behavior are essential in the environmental management system of any organization.

Previous studies on GHRM [4,5,7] have shown that GHRM affects employees' green, eco-friendly, or pro-environmental behaviors. Employees are expected to exhibit proenvironmental behavior, whether formal tasks related to the job or voluntary actions, e.g., taking green initiatives when they receive appropriate GHRM. A recent study on the hotel industry showed that high-performance HRM positively and significantly affects employee attitudes and behaviors [11]. The hotel's environmental management of HR was found to be significantly related to employee green behavior, i.e., organizational commitment and organizational citizenship behavior for the environment (OCBE) [12-14]. A recent study found that GHRM in general and green training in particular are the best predictors for individual environmental behavior and performance [15] GHRM also enhances eco-friendly behavior among hotel and tourism employees [5,16]. Moreover, GHRM was found to predict the two types of pro-environmental behaviors (task-related and proactive pro-environmental behavior) [3]. Drawing on resource-based view theory, a recent study on SMEs [8] showed that the leadership of small businesses, as a strategic resource in environmental management, has a direct, positive, and significant effect on GRHM, especially employee competencies and behavior. The same study also confirmed that GHRM policies and practices enhance employee abilities and competencies, and thus their environmental behaviors. Based on these arguments, it could be proposed that:

Hypothesis 1 (H1). GHRM has a positive effect on employee task-related pro-environmental behaviors in small tourism enterprises.

Hypothesis 2 (H2). GHRM has a positive effect on employee proactive pro-environmental behaviors in small tourism enterprises.

\subsection{GHRM and Environmental Performance}

Studies on strategic and/or high-performance HRM has shown a positive and direct relationship with both job performance and organizational performance [11,17]. Studies have shown that when employees receive proper HRM practices, e.g., proper training, development, and compensation, they are more likely to exhibit proper job performance, which affects the overall organizational performance [15]. In the environmental management literature, studies have shown that GHRM has a positive and direct effect on environmental performance $[4,5,18]$. More specifically, GHRM has been found to raise employee green consciousness and green behaviors [3,4], green innovation, as well as the environmental performance of the organization [8]. GHRM, especially green training and employee involvement, has been also found to directly and significantly influence hotel environmental performance [12].

GHRM also enhances green organizational culture and overall environmental performance of the organizations [18]. Research has found that businesses adopting formal environmental management systems are more likely to exhibit high environmental performance [19]. This formal environmental management system comprises GHRM policies and practices. However, small tourism businesses, e.g., small hotels, restaurants, and travel agencies, are less likely to adopt formal HRM practices due to limited resources and HR support [20]. Notwithstanding, the environmental management of leadership 
or owner/managers of these small tourism enterprises still has a positive effect on the environmental performances of these small businesses $[7,8]$. Hence, it could be hypothesized that:

Hypothesis 3 (H3). GHRM has a positive effect on environmental performance in small tourism enterprises.

\subsection{Pro-Environmental Behavior and Environmental Performance}

Pro-environmental behavior is among the various types of strategies considered by organizations to achieve environmental performance and promote environmental sustainability [21]. This includes all positive actions by employees directed to save natural resources or the environment and/or reduce the negative impact on the environment [3]. This comprises both proactive (or voluntary) green initiatives and task-related (or official green responsibilities in job description) green duties [6].

The limited published research on environmental management in the tourism context has shown that hotel employees' eco-friendly behavior positively, significantly, and directly affects environmental performance [5]. This eco-friendly behavior is equivalent to pro-environmental behavior which includes saving energy, conserving material, saving water recycling, as well as providing green initiatives [5]. Other research studies on employee green behavior and environmental performance $[12,13,22]$ have shown a positive relationship between employee OCBE and environmental performance. Based on these arguments, it could be hypothesized that:

Hypothesis 4 (H4). Task-related pro-environmental behavior has a positive effect on environmental performance in small tourism enterprises.

Hypothesis 5 (H5). Proactive pro-environmental behavior has a positive effect on environmental performance in small tourism enterprises.

\subsection{The Mediating Role of Pro-Environmental Behavior in the Relationship between GHRM and Environmental Performance}

Research has shown that GHRM has a direct link with employees' pro-environmental behaviors and environmental strategy of the organization $[3,8,12]$. It has also been confirmed that GHRM is a predictor of employee pro-environmental behaviors [3] and environmental performance [8]. An up-to-date research study examined different mediators in the relationship between GHRM and environmental performance. A study on the hotel industry showed that GHRM has a positive direct influence on environmental performance and indirect influence via employee commitment and eco-friendly behavior [5]. Another study on large hotels showed that OCBE mediates the influence of GHRM on hotel environmental performance [12]. Additionally, perceived organizational support has been found to influence individual environmental performance when employees are highly satisfied with organizational engagement [15].

A study on SMEs in the manufacturing industry showed that green innovation mediates the relationship between GHRM and environmental performance [8]. A third study on small lodging enterprises showed that green innovation partially mediates the relationship between owner-manager green ability, motivation, and opportunity (the three different dimensions of GHRM) and the environmental performance of these small lodging enterprises [7].

To the best of the researchers' knowledge, there is no published research (in English) that has examined the mediating role of both types of pro-environmental behaviors in the relationship between GHRM and environmental performance, especially on small tourism enterprises. This research makes the first attempt to examine this relationship. It is expected that employees' pro-environmental behaviors have a positive role in this relationship, similar to the positive mediating role of employee eco-friendly behavior in 
the relationship between GHRM and environmental performance. Hence, the following hypotheses can be proposed:

Hypothesis 6 (H6). Task-related pro-environmental behavior mediates the relationship between GHRM and environmental performance.

Hypothesis 7 (H7). Proactive pro-environmental behavior mediates the relationship between GHRM and environmental performance.

The literature review discussed above showed that despite the crucial role of GHRM in enhancing employee pro-environmental behaviors (task-related and proactive) and environmental performance of organizations, it could be clearly noticed that previous studies on the interrelationship between these variables are limited in the tourism context in general and very limited for small tourism enterprises in particular. This research examines these relationships in small tourism enterprises in the Egyptian context (see Figure 1).

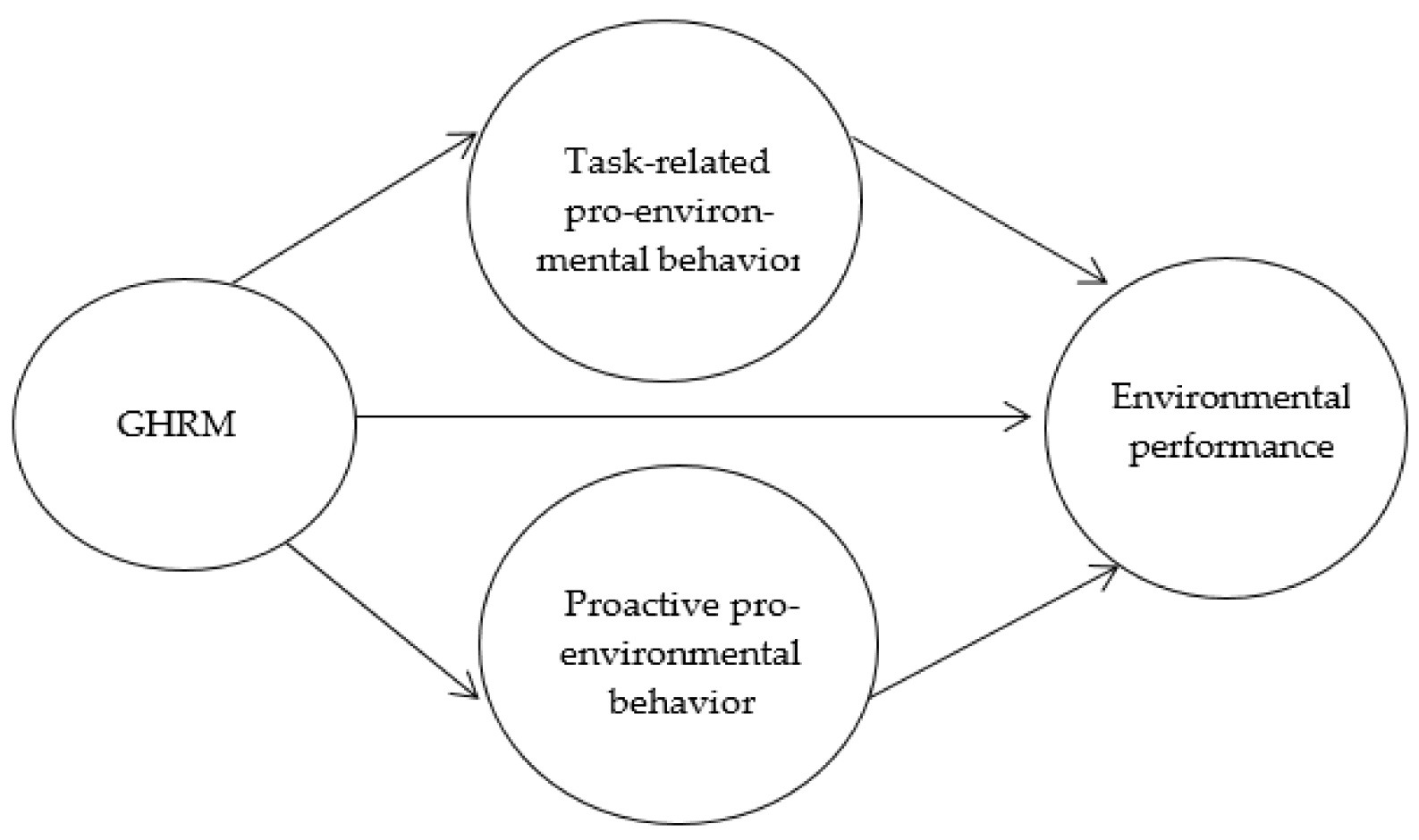

Figure 1. The research conceptual framework.

\section{Methodology}

\subsection{Research Population and Sample}

A quantitative research design was carried out using a survey research strategy and a self-administered questionnaire (see Appendix A) for data collection. All the study variables were adopted from previous well-established and widely used measures. The population of this study covers small tourism enterprises in Egypt. Small tourism enterprises contain small restaurants, hotels, and travel agencies that are funded by their owner and operated by their owner-manager or independent managers with often less than 50 workers [23]. The communication with several governmental authorities in Egypt declared that there is an unavailable database about small tourism enterprises; notwithstanding, there is evidence that comprehends the major proportion of small tourism enterprises in the tourism industry in Egypt [22]. A total of 800 questionnaires were self-administrated during July and August 2020, employing the drop and collect technique, which increases the response rate [24]. Respondents in this study were identified via a personal network. 
The authors work in the Colleges of Tourism and Hotel Management in Egypt. Hence, they have a good network with hospitality enterprises, including small tourism enterprises. The collection process yielded 560 valid responses for analysis with a response rate of $70 \%$. This research sample size was compared favorably with similar studies on small enterprises $[7,8,25]$.

\subsection{Measure and Questionnaire Development}

The authors derived the study measure from widely employed, reliable, and validated measures in previous studies. GHRM was measured by six items $(a=0.981)$ derived from [26]. The sample variables were "My enterprise encourages employees to provide suggestions on environmental improvement"; "Employees fully understand the extent of corporate environmental policy"; and "My enterprise provides adequate training to promote environmental management as a core organizational value". Task-related proenvironmental behavior was operationalized by employing [27] a scale; the scale had three items: $(a=0.960)$ "I adequately completed assigned duties in environmentally friendly ways" and "I fulfilled responsibilities specified in my job description in environmentally friendly ways". Similarly, we measured proactive pro-environmental behavior by three items $(a=0.964)$ adapted from [28]; the sample variables were "I took a chance to get actively involved in environmental protection at work" and "I took the initiative to act in environmentally friendly ways at work". Finally, a seven-item scale $(a=0.980)$ derived from $[5,29]$ was employed to measure environmental performance. The sample items included "environmental management within our enterprise has reduced wastes, conserve water usage, and conserved energy usage". A five-point Likert type rating scale was employed, where $1=$ "strongly disagree" and $5=$ "strongly agree".

The questionnaire was mainly in its original English version and then translated into Arabic, and consequently validated employing back-translation by an English-Arabic professional; the two English forms were consistent. The questionnaire was pre-tested with five academics in tourism and hotel faculties, six professionals in the tourism industry, and 10 employees in small hotels and travel agencies. All were requested to assess the scale variables for content validity and note any observations that could be employed to revise the scales. The comments were then employed to improve the clarity and relevance of the research instrument. Finally, a pilot survey was conducted with 10 employees in small hotels and travel agencies. Based on the respondents' feedback, the questionnaire variables were refined, and a modified final version was designed. The pilot test feedback provided positive comments on the content validity of the questionnaire variables. This feedback further clarified and improved the questionnaire content.

\subsection{Data Analysis}

Some successive data analysis techniques were employed as follows. First, descriptive statistics were employed to investigate the respondents' profiles and the statuses of enterprises. Second, subsequently, a first-order confirmatory factor analysis (CFA) was conducted to test the validity and reliability of the study's outer model (measurement model). Following suggestions from [30], model goodness of fit measures, such as $\chi^{2} / \mathrm{df}$, root mean square error of approximation (RMSEA), comparative fit index (CFI), and standardized root mean squared residual (SRMR), were estimated to analyze the model data to fit the previously theorized model. Third, the authors carried out structural equation modeling with Amos vs. 21 graphics for hypotheses testing, as shown in Figure 2. SEM was employed, as it permits the comprehensive and concurrent inspection of all theorized hypotheses for multidimensional and complicated phenomena [31], considering the possible measurement error as well [26].

To spot the difference in the mean values between early and late collected questionnaires, an independent sample t-test analysis was used. No statistical differences were observed $(p>0.05)$, which gives evidence that non-response bias is not an issue in this study [32]. 
A quantitative research design using survey research strategy and self-administered questionnaire to collect data was employed, all the study variables were adopted from previous widely used measures

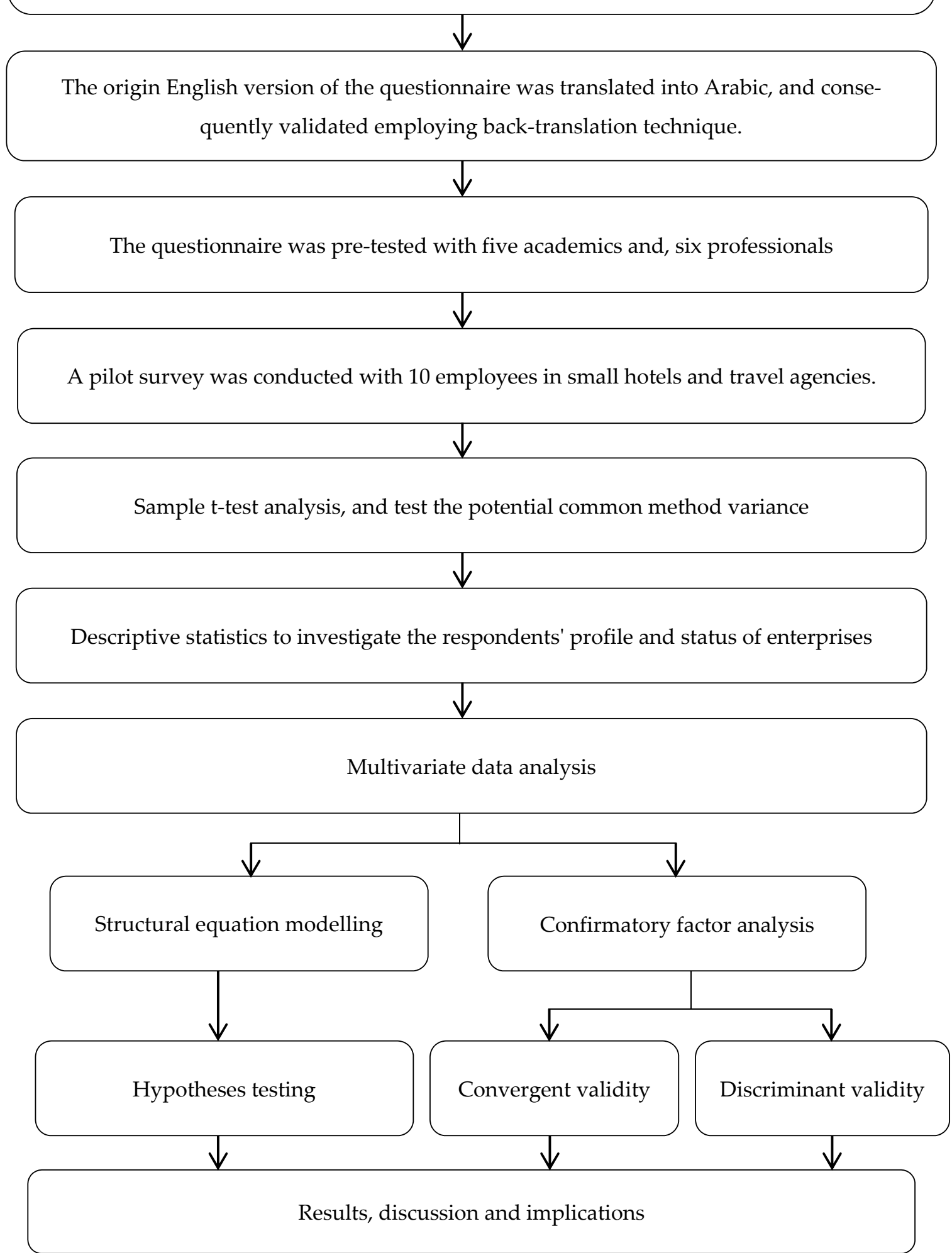

Figure 2. Summary of the employed research methods. 
To test the potential common method variance (CMV) that might arise from collecting dependent and independent information from the same respondent, four procedures, as suggested by [33], were adopted. (1) All participants were guaranteed that their information was saved confidentially and anonymously. (2) The questionnaire was created where dependent items were located before the independent variables. (3) The scale was pilot tested with 20 practitioners and 20 academic and refined accordingly. (4) Harman's single factor test was conducted; all the questionnaire items were subjected to exploratory factor analysis (EFA), and the extracted choice was fixed to the value of 1 with no rotation option. Subsequently, one dimension arose, which explains $41.5 \%$ of the variance. Taken together, the preceding procedures show that CMV is not an issue in this study.

The mean (M) scores were between 3.82 and 4.22; the minimum standard deviation (S.D) value was 0.785 ; the maximum S.D. was 1.160 , which indicates that the study data are more dispersed and less centralized around its mean [34].

\section{Results}

\subsection{The Profiles of Respondents}

As discussed above, the questionnaire was handed to employees in small hotels and travel agencies. The vast majority of respondents in small hotels were males (85.3\%), whereas males were slightly higher than females in travel agencies (55\%) (Table 1). In relation to age, the profiles were similar in both small hotels and travel agencies, as $44.1 \%$ and $43.2 \%$ were aged between 30 and 45 years, 45.3 and 31.8 less than 30 years old, and 20.6 and 25 between 46 and 60 years old for small hotels and travel agencies, respectively. Most of the respondents held a university degree (55.9\% and $72.8 \%$ in small hotels and small travel agencies, respectively). Regarding the types of employees, more than three-quarters of the respondents (82.4) were temporary or casual workers (hourly paid). This proportion was slightly lower in small travel agencies, but still more than half of the respondents $52.3 \%$ (Table 1).

Table 1. The profile of respondents.

\begin{tabular}{cccccc}
\hline & & \multicolumn{2}{c}{ Small Hotels } & \multicolumn{2}{c}{ Small Travel Agencies } \\
\hline \multirow{3}{*}{ Gender } & Male & Frequency & Percentage & Frequency & Percentage \\
& Female & 290 & 85.3 & 99 & 45 \\
& Less than 30 years & 120 & 14.7 & 121 & 55 \\
\hline \multirow{2}{*}{ Age } & 30 to 45 years & 150 & 35.3 & 70 & 31.8 \\
& 46 to 60 years & 70 & 20.6 & 95 & 43.2 \\
& More than 60 years & - & - & 55 & 25 \\
Education level & High school degree & 150 & 44.1 & 40 & - \\
& University graduate & 190 & 55.9 & 160 & 19.1 \\
& Post-graduate & - & - & 20 & 72.8 \\
Type of & Salary employees & 60 & 17.6 & 105 & 9.1 \\
\hline employees & Hourly employees & 280 & 82.4 & 115 & 47.7 \\
\hline
\end{tabular}

\subsection{Measurement Model}

Table 2 shows the convergent and discriminant validity of the employed scales. The validity of the employed measures was examined by conducting first-order confirmatory factor analysis (CFA) with Amos vs. 21. The CFA model showed a good fit: $\chi^{2}(146$, $\mathrm{N}=560)=552.442, p<0.001$, normed $\chi^{2}=3.777, \mathrm{RMSEA}=0.042, \mathrm{SRMR}=0.036 ; \mathrm{CFI}=0.963$ (see Table 2). As per the suggestions in [35], three conditions should be met to approve convergent validity: (1) The item loading on its related factor should exceed 0.7 [35]. (2) Composite reliability [CR] should be more than 0.70 . (3) The average variance extracted (AVE) should be greater than 0.50. All the three previous conditions were met, which approves the convergent validity of the study measures [36]. All loadings (see Figure 3) were between 0.891 and 0.98 and were above 0.7 with minimum $t$-values exceeding 41.16 
(Table 2). The CR values for all factors were above 0.7 , and the AVE values for all dimensions exceeded the threshold value of 0.50 (Table 3 ), which guarantees convergent validity as endorsed by [36].

Table 2. CFA Factor loading: $t$-value (C.R), $M$ (mean), and standard deviation (S.D.).

\begin{tabular}{|c|c|c|c|c|}
\hline Dimensions and Variables & Factor Loading & $t$-Value & $\mathbf{M}$ & S.D. \\
\hline \multicolumn{5}{|l|}{$\begin{array}{l}\text { “Green Human Resource Management [26], }(\mathrm{a}=0.981),(\mathrm{CR}=0.986, \mathrm{AVE}=0.924 \text {, } \\
\mathrm{MSV}=0.511)\end{array}$} \\
\hline $\begin{array}{l}\text { GRHRM_1: My enterprise provides adequate training to promote environmental } \\
\text { management as a core organizational value. }\end{array}$ & 0.980 & F & 4.03 & 0.863 \\
\hline $\begin{array}{l}\text { GRHRM_2: My enterprise considers how well employee is doing at being } \\
\text { eco-friendly as part of their performance appraisals. }\end{array}$ & 0.967 & 53.972 & 4.01 & 0.887 \\
\hline $\begin{array}{l}\text { GRHRM_3: My enterprise relates to employee's eco-friendly behavior to rewards } \\
\text { and compensation. }\end{array}$ & 0.972 & 50.201 & 4.01 & 0.873 \\
\hline $\begin{array}{l}\text { GRHRM_4: My enterprise considers personal identity-environmental } \\
\text { management fit in recruitment and selection. }\end{array}$ & 0.972 & 51.611 & 4.03 & 0.871 \\
\hline $\begin{array}{l}\text { GRHRM_5: Employees fully understand the extent of corporate } \\
\text { environmental policy. }\end{array}$ & 0.943 & 51.595 & 4.00 & 0.926 \\
\hline $\begin{array}{l}\text { GRHRM_6: My enterprise encourages employees to provide suggestions on } \\
\text { environmental improvement. }\end{array}$ & 0.933 & 44.908 & 3.97 & 0.934 \\
\hline \multicolumn{5}{|l|}{$\begin{array}{l}\text { Task-related pro-environmental behavior [27], }(a=0.960),(\mathrm{CR}=0.961 \text {, } \\
\mathrm{AVE}=0.891, \mathrm{MSV}=0.334)\end{array}$} \\
\hline Task_1: Performance appraisal records environmental performance & 0.967 & $\mathrm{~F}$ & 4.21 & 0.836 \\
\hline $\begin{array}{l}\text { Task_2: Performance appraisal includes environmental incidents, responsibilities, } \\
\text { concerns and policy }\end{array}$ & 0.958 & 53.840 & 4.21 & 0.815 \\
\hline Task_3: Employee gets reward for environmental management. & 0.905 & 42.038 & 4.22 & 0.785 \\
\hline \multicolumn{5}{|l|}{$\begin{array}{l}\text { Proactive pro-environmental behavior }[28],(a=0.964),(\mathrm{CR}=0.965, \mathrm{AVE}=0.901, \\
\mathrm{MSV}=0.334)\end{array}$} \\
\hline Proact_1: Employees are involved to become environmentally friendly & 0.974 & $\mathrm{~F}$ & 3.99 & 0.922 \\
\hline Proact_2: Using teamwork for resolving environmental issues & 911 & 42.921 & 4.07 & 0.872 \\
\hline Proact_3: Employees to discuss environmental issues in team meetings & 0.961 & 58.997 & 4.03 & 0.849 \\
\hline \multicolumn{5}{|l|}{$\begin{array}{l}\text { Environmental Performance }[5,29](a=0.980)(C R=0.983, \mathrm{AVE}=0.890, \\
\mathrm{MSV}=0.511)\end{array}$} \\
\hline $\begin{array}{l}\text { Envir_Perf_1: Environmental management within our enterprise has } \\
\text { reduced wastes }\end{array}$ & 0.972 & $\mathrm{~F}$ & 3.96 & 0.995 \\
\hline $\begin{array}{l}\text { Envir_Perf_2: Environmental management within our enterprise has conserved } \\
\text { water usage }\end{array}$ & 0.970 & 67.101 & 3.93 & 1.009 \\
\hline $\begin{array}{l}\text { Envir_Perf_3: Environmental management within our enterprise has conserved } \\
\text { energy usage }\end{array}$ & 0.956 & 60.023 & 3.91 & 1.032 \\
\hline $\begin{array}{l}\text { Envir_Perf_4: Environmental management has reduced purchases of } \\
\text { non-renewable materials, chemicals, and components. }\end{array}$ & 0.943 & 54.830 & 3.93 & 1.009 \\
\hline Envir_Perf_5: Environmental management has reduced overall costs & 0.907 & 44.865 & 3.87 & 1.092 \\
\hline $\begin{array}{l}\text { Envir_Perf_6: Environmental management has reduced wastes Improved its } \\
\text { position in the marketplace }\end{array}$ & 0.891 & 41.617 & 3.82 & 1.160 \\
\hline $\begin{array}{l}\text { Envir_Perf_7: Environmental management has helped enhance the reputation of } \\
\text { our enterprise" }\end{array}$ & 0.966 & 65.097 & 3.92 & 1.012 \\
\hline
\end{tabular}

Model fit $\left(\chi^{2}(146, N=560)=552.442, p<0.001\right.$, normed $\chi^{2}=3.777$, RMSEA $=0.042$, SRMR $=0.036$, CFI $=0.963$, TLI $=0.974$, NFI $=0.962$, $\mathrm{PCFI}=0.743$ and PNFI $=0.777)$. Note: $\mathrm{CR}=$ composite reliability, $\mathrm{AVE}=$ average variance extracted, $\mathrm{MSV}=$ maximum shared value. $\mathrm{F}$ : fixed to set the scales. $\mathrm{M}=$ mean, S.D. = standard deviation".

To assess discriminant validity, the recommendations in [26,36] were followed. The AVE square root for each factor should be more than the values of the shared correlations of other factors in both the row and column [36]. Moreover, the AVE scores should exceed the maximum shared value (MSV) for each factor [22] (Table 3). As revealed in Tables 2 and 3, the discriminant validity conditions were met and guaranteed. 


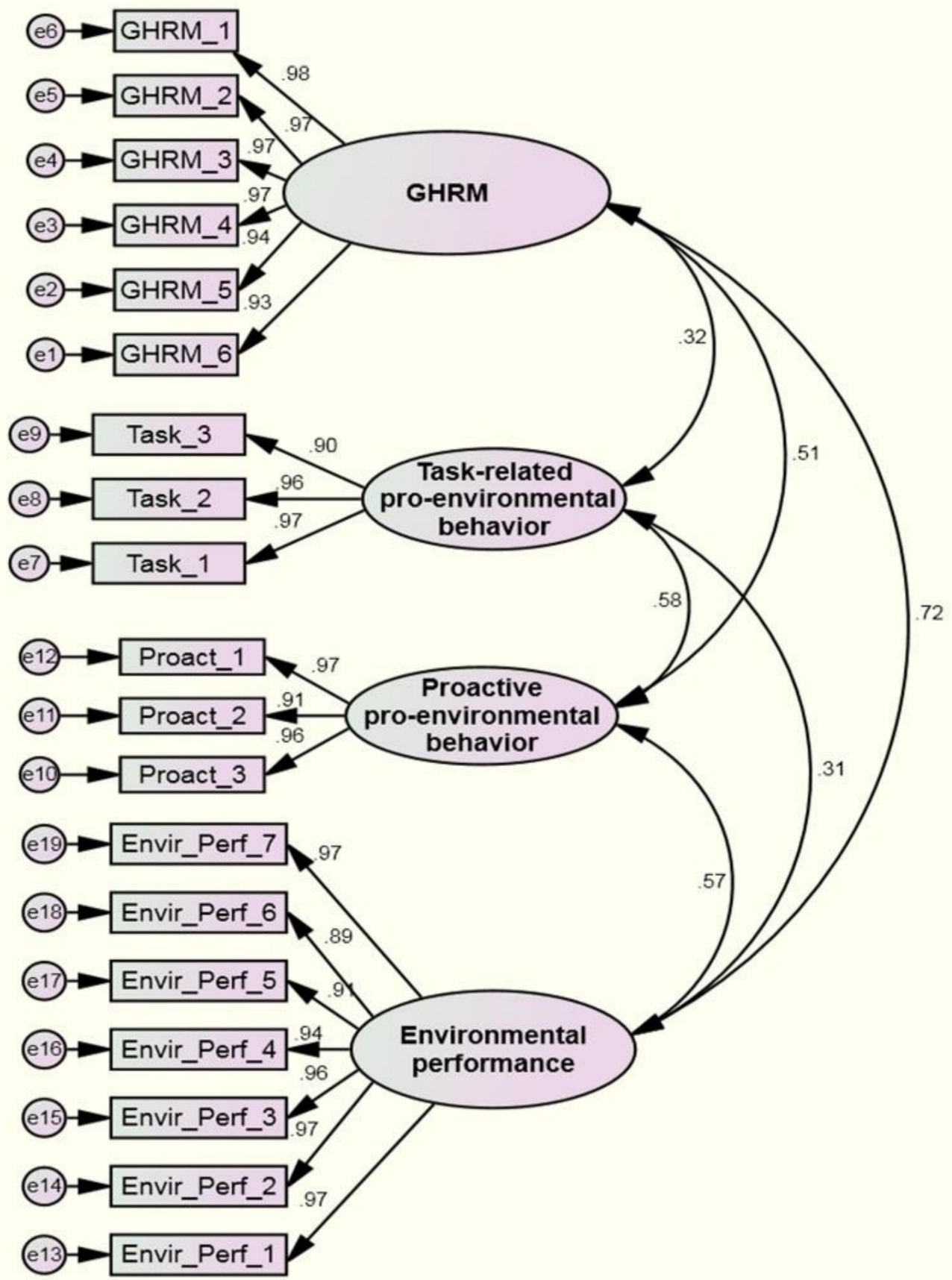

Figure 3. The first order confirmatory factor analysis (CFA).

Table 3. Discriminant validity based on Fornell-Larcker criterion analysis.

\begin{tabular}{lcccc}
\hline & $\mathbf{1}$ & $\mathbf{2}$ & $\mathbf{3}$ & $\mathbf{4}$ \\
\hline 1-Proactive pro-environmental behavior & $\mathbf{0 . 9 4 9}$ & & & \\
2-GHRM & 0.512 & $\mathbf{0 . 9 6 1}$ & & \\
3-Task-related pro-environmental behavior & 0.578 & 0.316 & $\mathbf{0 . 9 4 4}$ & $\mathbf{0 . 9 4 4}$ \\
4-Environmental performance & 0.567 & 0.715 & 0.314 & \\
\hline Note: Bold diagonal numbers represent the average variance extracted (AVEs) for the related dimension.
\end{tabular}




\subsection{Structural Model}

To test the study hypotheses, the researchers ran SEM with the maximum likelihood method and employed Amos vs. 21 graphics. Overall, the SEM results revealed a good model fit to data $\left(\mathrm{X}^{2}=662.235, \mathrm{df}=147(\mathrm{n}=560), p<0.001 ; \mathrm{CFI}=0.951\right.$; $\mathrm{SRMR}=0.044$; RMSEA $=0.049)$ (Table 4). Moreover, the model has good explanatory power $(\mathrm{SMC})$, as the dependent variables can explain 0.60 of variance in environmental performance.

Table 4. The results of the structural model.

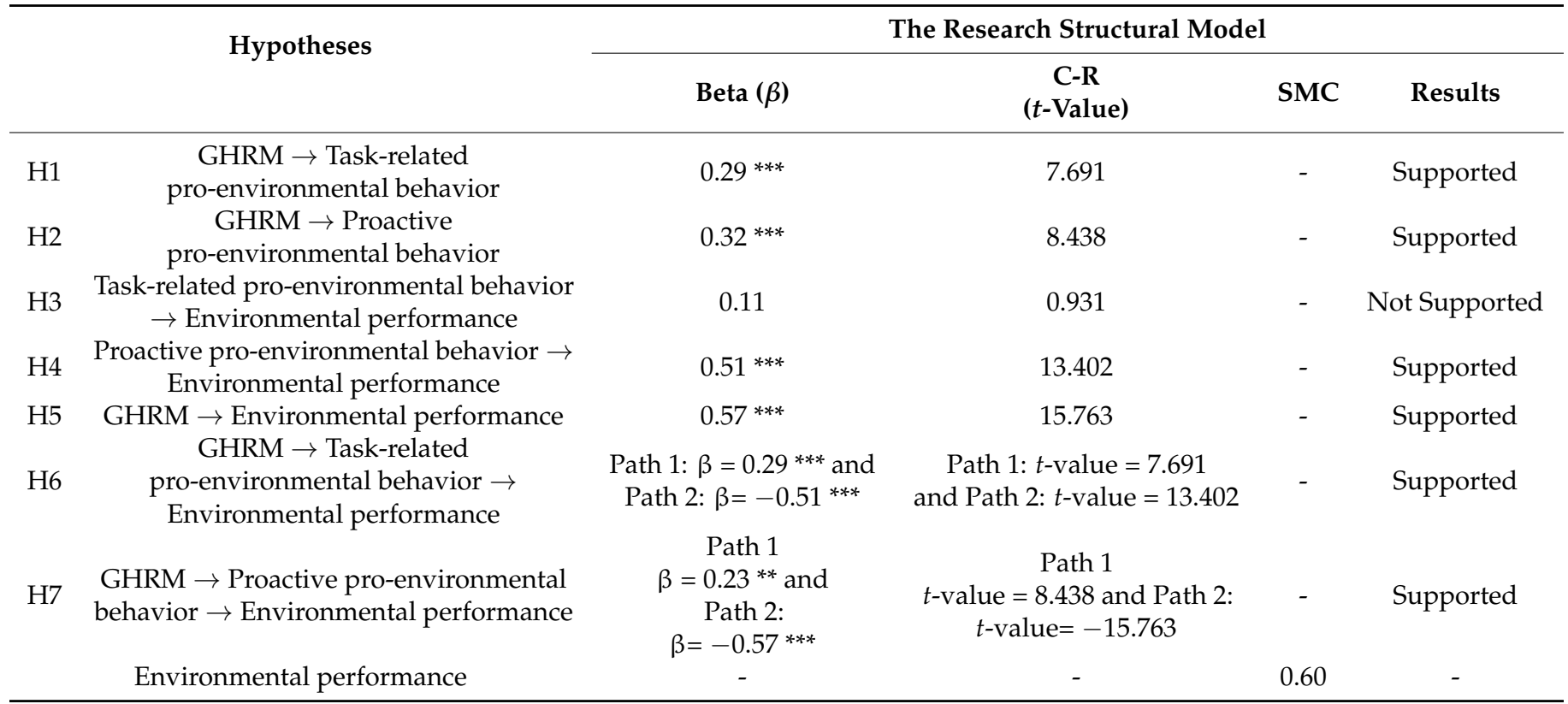

Model fit $\left(\chi^{2}(147, \mathrm{~N}=560)=662.235, p<0.001\right.$, normed $\chi^{2}=4.505$, RMSEA $=0.049$, SRMR $=0.0 .044, \mathrm{CFI}=0.951, \mathrm{TLI}=0.948, \mathrm{NFI}=0.952$, PCFI $=0.834$ and PNFI $=0.778),{ }^{* * *} p<0.001$. SMC $=$ Squared Multiple correlations .

The results of the SEM structural model are shown in Table 4 and Figure 4. The results show the direct and indirect relationships in this study. The SEM outputs supported the direct positive and significant impacts of GHRM on both task-related pro-environmental behavior $(\beta=0.29, t$-value $=7.691, p<0.001)$ and proactive pro-environmental behavior ( $\beta=0.32$, $t$-value $=8.438, p<0.001)$; accordingly, hypotheses $\mathrm{H}_{1}$ and $\mathrm{H}_{2}$ were supported. Nevertheless, the direct effect of GHRM on environmental performance was positive but insignificant $(\beta=0.11, t$-value $=0.931, p=0.352)$, and accordingly, hypothesis $\mathrm{H}_{3}$ was not supported. The SEM results also showed a high positive and significant impact of task-related pro-environmental behavior on environmental performance $(\beta=0.51$, $t$-value $=13.402, p<0.001$ ), which supported hypothesis $\mathrm{H}_{4}$. Similarly, proactive proenvironmental behavior was found to have a high positive and significant impact on environmental performance ( $\beta=0.57, t$-value $=15.763, p<0.001)$; hence, hypothesis $\mathrm{H}_{5}$ was supported.

To test the mediation impacts, the authors followed the suggestions from $[27,37]$. Full mediation can only be accepted if the indirect effects are significant, while the direct path is not; if both direct and indirect paths are significant, partial mediation is established [37]. Consequently, the SEM results in Table 4 show that the indirect relationships (the relationship between GHRM and environmental performance through task-related pro-environmental behavior and proactive pro-environmental behavior) are significant, while the direct one (the direct path from GHRM to environmental performance) is insignificant in this study, which indicates that both task-related pro-environmental behavior and proactive pro-environmental behavior can fully mediate the relationships between GHRM and environmental performance. The previous conclusion is further confirmed by inspecting the SEM output of the standardized indirect impacts from GHRM to environmental 
performance. The insignificant direct effect of GHRM on environmental performance increased from $\beta=0.11, p=0.352$ to a total significant effect of $\beta=0.79, p<0.001$. The previous results further support the full mediation of both task-related pro-environmental behavior and proactive pro-environmental behavior in the relationship between GHRM and environmental performance.

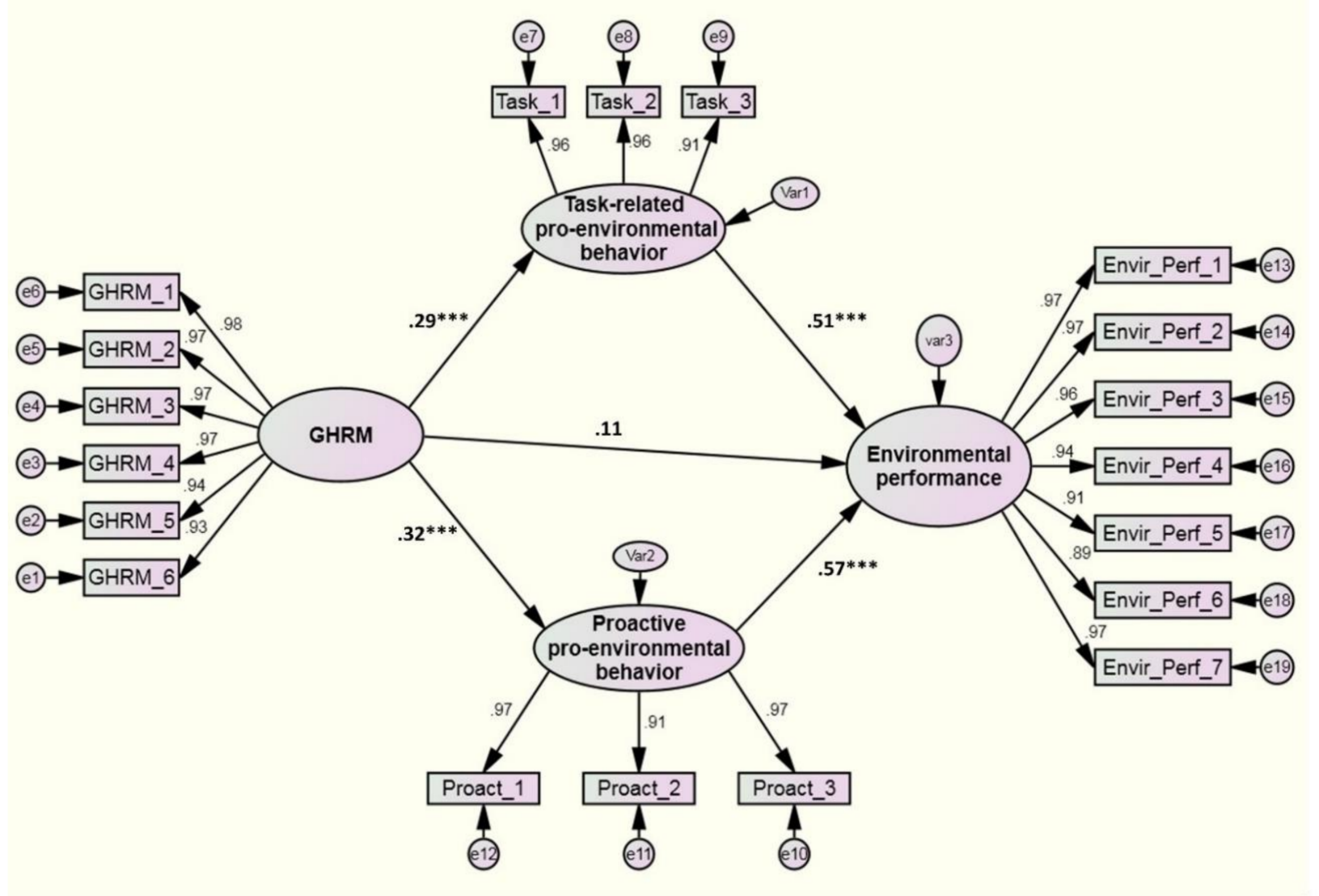

Figure 4. The research structural model. ${ }^{* *} p<0.001$.

\section{Discussion}

This research was established to bridge the gap in knowledge in relation to the interrelationship between GHRM, employee pro-environmental behaviors (both task-related and proactive pro-environmental behavior), and environmental performance in small tourism establishments, particularly small hotels and travel agencies in Egypt. The research started by developing a conceptual framework based on previous studies on GHRM, employee pro-environmental behavior, and environmental performance with a specific focus on small enterprises wherever possible. The results of SEM showed that GHRM positively and directly influences both task-related and proactive pro-environmental behaviors of employees in small tourism enterprises. The results showed that when small tourism enterprises consider environmental management in the selection of the right person, provide adequate environmental training, reward eco-friendly behavior, and have an environmental policy, employees responded by exhibiting proper task-related pro-environmental behavior. This could be clearly noticed in the performance appraisal of employees' environmental incidents, responsibilities, concerns, and policy. Additionally, GHRM was found to predict proactive employee behavior. In other words, in small tourism enterprises that encourage their employees to provide suggestions and initiatives in environmental improvements, employees are more likely to become environmentally friendly and work in a team to 
resolve any environmental issues. These findings support previous studies [3,5] in which GHRM positively affects employee green, ecofriendly, or pro-environmental behaviors.

The results also showed that both types of pro-environmental behavior (task-related and proactive) significantly and positively affect environmental performance. This means that both types of pro-environmental behavior have a significant positive effect on waste reduction, conserving water and energy usage, reduction in purchasing non-renewable materials, reduction in overall cost, and enhancing the reputation and marketplace position of the organization. These results coincide with a previous study [5] in which employee eco-friendly behavior affects and enhances environmental performance. It also supports other work [12,13] in which voluntary pro-environmental behavior, such as OCBE, has a direct influence on the environmental performance of large businesses. The results of current research confirm this finding in the small tourism enterprise context.

Unlike the results of many previous studies $[5,7,8]$, the results of this research, surprisingly, showed that GHRM does not have a significant impact on environmental performance in small tourism enterprises. This could be because the vast majority of employees in small tourism enterprises are part-timers. Earlier research on part-time employees $[38,39]$ showed that they are not a homogenous group and should be treated differently in comparison to full-time employees to achieve appropriate performance. It is, therefore, essential that small tourism enterprises pay sufficient attention, when selecting part-time employees, to their pro-environmental behavior and invest in them appropriately. However, the results showed that pro-environmental employee behavior fully mediates the relationship between GHRM and environmental performance, which encourages small tourism enterprises to put more emphasis on the pro-environmental behavior of their employees. This finding confirms the work of previous studies $[12,13]$ in which pro-environmental behavior, i.e., OCBE, mediates the effect of GHRM on environmental performance. However, such studies were undertaken on large businesses. This research confirms this finding in the small tourism enterprises context.

\section{Implications of the Study}

The research provides several theoretical implications, especially for tourism and hospitality scholars. First, the research contributes to the limited studies on GHRM, employee pro-environmental behavior, and environmental performance in small businesses, particularly small tourism enterprises. It advances understanding regarding the interrelationship between GHRM, employee pro-environmental behavior, and environmental performance in small tourism enterprises. The research showed that GHRM positively and significantly affects pro-environmental behavior and pro-environmental behavior positively and significantly affects the environmental performance of small tourism enterprises. Second, the research confirmed the mediating role of pro-environmental behavior in the relationship between GHRM and environmental performance in small tourism enterprises. Third, the research did not confirm the direct significant effect of GHRM on environmental performance. This confirms that the results of GHRM on large businesses and small businesses in another context cannot always be generalized to all small tourism enterprises. Thus, scholars need to be cautious when generalizing the results to another context. Fourth, further attention should be paid to fully examine and understand the two types of employee pro-environmental behavior (task-related and proactive), since it plays a fully mediating role between GHRM and environmental performance.

The research has several implications for tourism practitioners, especially those in small hotels and travel agencies. First, owners-managers and/or managers of small tourism enterprises need to pay more attention to recruiting and selecting employees with pro-environmental behaviors. A personality test confirming these types of behavior should be conducted before selecting the right employees. This practice ensures that the new candidates fit with the environmental management policy of the organization. Second, owners-managers and /or managers of small tourism enterprises should recognize the heterogeneity of their temporary employees. The majority of employees in current research 
are temporary workers on an hourly or casual basis. Studies [38,39] should consider that temporary employees are not a homogenous group, and recognizing this heterogeneity helps in selecting the right people with pro-environmental behavior that fits organization policy, e.g., environmental management policy. Third, investment in temporary employees is urgently needed to ensure positive pro-environmental behavior. Research [40] has shown that if temporary employees perceive lower investment, they are more likely to respond with a negative attitude and behavior. Hence, proper environmental training should be provided to new employees to enhance their new positive pro-environmental behavior.

\section{Limitations and Opportunities for Further Research}

This research paper was conducted on small tourism enterprises in Egypt. The classification of this type of enterprise often varies from one country to another and occasionally from one industry to another. The current study investigated hotels and travel agencies with less than 50 workers, the majority with less than 25 workers, thus limiting the generalization of the results to a wider population. It is, therefore, suggested for further research to gather data in another context (country and/ or industry) to validate the current study results. Further research could test the hypotheses of this study in different categories of tourism enterprises, e.g., luxury five-star hotels and in a different country as well. Further research could also conduct a multigroup analysis approach [41,42] to differentiate between the results of hotel and travel agencies, and additionally, the duration of work experience could be employed in further studies as a moderating variable. The cross-sectional employed approach to gathering the required data in this study could have limited the causality purposes in this paper. Further research could also take into consideration the effects of peer to peer sharing economy services for hospitality, such as Airbnb, in the employment process in small tourism enterprises and how these can affect the tested relationships. In any study in which SEM if employed to infer causality, a longitudinal research approach is preferred to support more solid inferences [43].

Author Contributions: Conceptualization, I.A.E., A.E.E.S., A.M.S.A., and M.A.; methodology, I.A.E., A.E.E.S., and A.M.S.A.; software, I.A.E. and A.E.E.S.; validation, A.E.E.S., A.M.S.A., and I.A.E.; formal analysis, I.A.E., A.E.E.S., and A.M.S.A.; investigation, M.A., A.M.S.A., A.E.E.S., and I.A.E.; resources, I.A.E. and A.E.E.S.; data curation, A.E.E.S. and I.A.E.; writing-original draft preparation, I.A.E., A.E.E.S., A.M.S.A., and M.A.; writing-review and editing, A.E.E.S. and I.A.E.; visualization, I.A.E.; supervision, I.A.E. and A.E.E.S.; project administration, A.E.E.S., I.A.E., A.M.S.A., and M.A.; funding acquisition, I.A.E. All authors have read and agreed to the published version of the manuscript.

Funding: The authors extend their appreciation to the Deputyship for Research and Innovation, Ministry of "Education" in Saudi Arabia, for funding this research work through the project number IFT20120.

Institutional Review Board Statement: The study was conducted in accordance with the Declaration of Helsinki, and the protocol was approved by the Institutional Financing Committee (Project number IFT 20120, approval date 10 July 2020).

Informed Consent Statement: Informed consent was obtained from all subjects involved in the study.

Data Availability Statement: Data available on request due to privacy/ethical restrictions.

Conflicts of Interest: The authors declare no conflict of interest. 


\section{Appendix A. Questionnaire Used in This Study \\ Dear participant, \\ This questionnaire was designed to identify the Effect of green human resource man- agement on environmental performance with the mediating role of pro-environmental behaviors your contribution will be appreciated; your answers will be kept strictly confi- dential and will be used only for research purposes. The analysis of the survey will involve statistical aggregates making the individual responses impossible to be identified.}

Please circle the one number for each question that comes closest to reflecting your perception about it where 1 means strongly disagree and 5 means strongly agree

\begin{tabular}{|c|c|c|}
\hline \multicolumn{3}{|c|}{ Section 1: Measures of Environmental Performance } \\
\hline 1 & Environmental management within our enterprise has reduced wastes & 12345 \\
\hline 2 & Environmental management within our enterprise has conserved water usage & 12345 \\
\hline 3 & Environmental management within our enterprise has conserved energy usage & 12345 \\
\hline 4 & Environmental management has reduced purchases of non-renewable materials, chemicals, and components. & 12345 \\
\hline 5 & Environmental management has reduced overall costs & 12345 \\
\hline 6 & Environmental management has reduced wastes Improved its position in the marketplace & 12345 \\
\hline 7 & Environmental management has helped enhance the reputation of our enterprise" & 12345 \\
\hline \multicolumn{3}{|c|}{ Section 2: Measures of Proactive pro-environmental behavior } \\
\hline & We are involved to become environmentally friendly & 12345 \\
\hline 9 & We regularly involved in teamwork for resolving environmental issues & 12345 \\
\hline & Employees are encouraged to discuss environmental issues in team meetings & 12345 \\
\hline \multicolumn{3}{|c|}{ Section 3: Measures of Task-related pro-environmental behavior } \\
\hline & Performance appraisal records environmental performance & 12345 \\
\hline & Performance appraisal includes environmental incidents, responsibilities, concerns and policy & 12345 \\
\hline & Employee gets reward for environmental management. & 12345 \\
\hline \multicolumn{3}{|c|}{ Section 4: Measures of Green Human Resource Management } \\
\hline & My enterprise provides adequate training to promote environmental management as a core organizational value. & 12345 \\
\hline & My enterprise considers how well employee is doing at being eco-friendly as part of their performance appraisals. & 12345 \\
\hline & My enterprise relates to employee's eco-friendly behavior to rewards and compensation. & 12345 \\
\hline & My enterprise considers personal identity-environmental management fit in recruitment and selection. & 12345 \\
\hline & Employees fully understand the extent of corporate environmental policy. & 12345 \\
\hline 19 & My enterprise encourages employees to provide suggestions on environmental improvement. & 12345 \\
\hline
\end{tabular}

Optional questions (section Four)

Name .............

Type of Organization: Hotel $\lceil\quad$ Restaurant $\lceil\quad$ Travel agent \lceil

Gender: Male $\ulcorner\quad$ Female $Г$

Marital status: Unmarried $\Gamma \quad$ Married $\Gamma$

Educational level: $\quad$ High school degree $\quad \Gamma \quad$ University graduate $\lceil\quad$ Post-graduate $\Gamma$

Age: less than $30 \quad$ 30-45 $Г$

Type of employees: $\quad$ Salary employees \lceil

46-60 $\Gamma \quad$ More than 60

Hourly employees $\Gamma$

Your email address ................

\section{References}

1. Hawkem, P.; Lovin, A.B.; Lovins, L.H. Natural Captalisim: Creating the Next Industrial Revolution; Little, Brown: Boston, MA, USA, 1999.

2. Elkington, J. 25 years ago I coined the phrase “triple bottom line. Here's why it's time to rethink it. Harv. Bus. Rev. 2018, 25, 2-5. 
3. Chaudhary, R. Green human resource management and employee green behavior: An empirical analysis. Corp. Soc. Responsib. Environ. Manag. 2020, 27, 630-641. [CrossRef]

4. Renwick, D.W.; Redman, T.; Maguire, S. Green human resource management: A review and research agenda. Int. J. Manag. Rev. 2013, 15, 1-14. [CrossRef]

5. Kim, Y.J.; Kim, W.G.; Choi, H.M.; Phetvaroon, K. The effect of green human resource management on hotel employees' eco-friendly behavior and environmental performance. Int. J. Hosp. Manag. 2019, 76, 83-93. [CrossRef]

6. Bissing-Olson, M.J.; Iyer, A.; Fielding, K.S.; Zacher, H. Relationships between daily affect and pro-environmental behavior at work: The moderating role of pro-environmental attitude. J. Organ. Behav. 2013, 34, 156-175. [CrossRef]

7. Sobaih, A.E.E.; Hasanein, A.; Elshaer, I. Influences of Green Human Resources Management on Environmental Performance in Small Lodging Enterprises: The Role of Green Innovation. Sustainability 2020, 12, 10371. [CrossRef]

8. Singh, S.K.; Del Giudice, M.; Chierici, R.; Graziano, D. Green innovation and environmental performance: The role of green transformational leadership and green human resource management. Technol. Forecast. Soc. Chang. 2020, 150, 119762. [CrossRef]

9. Singh, S.K.; El-Kassar, A.N. Role of big data analytics in developing sustainable capabilities. J. Clean. Prod. 2019, 213, 1264-1273. [CrossRef]

10. Norton, T.A.; Zacher, H.; Ashkanasy, N.M. Pro-environmental organizational culture and climate. In The Psychology of Green Organizations; Oxford University Press: Oxford, UK, 2015.

11. Sobaih, A.E.E.; Ibrahim, Y.; Gabry, G. Unlocking the black box: Psychological contract fulfillment as a mediator between HRM practices and job performance. Tour. Manag. Perspect. 2019, 30, 171-181. [CrossRef]

12. Pham, N.T.; Thanh, T.V.; Tučková, Z.; Thuy, V.T.N. The role of green human resource management in driving hotel's environmental performance: Interaction and mediation analysis. Int. J. Hosp. Manag. 2020, 88, 102392. [CrossRef]

13. Anwar, N.; Mahmood, N.H.N.; Yusliza, M.Y.; Ramayah, T.; Faezah, J.N.; Khalid, W. Green Human Resource Management for organisational citizenship behaviour towards the environment and environmental performance on a university campus. J. Clean. Prod. 2020, 256, 120401. [CrossRef]

14. Yen, C.H.; Chen, C.Y.; Teng, H.Y. Perceptions of environmental management and employee job attitudes in hotel firms. J. Hum. Resour. Hosp. Tour. 2013, 12, 155-174. [CrossRef]

15. Paillé, P.; Valéau, P.; Renwick, D.W. Leveraging green human resource practices to achieve environmental sustainability. J. Clean. Prod. 2020, 260, 121137. [CrossRef]

16. Yong, J.Y.; Yusliza, M.Y.; Ramayah, T.; Chiappetta Jabbour, C.J.; Sehnem, S.; Mani, V. Pathways towards sustainability in manufacturing organizations: Empirical evidence on the role of green human resource management. Bus. Strategy. Environ. 2020, 29, 212-228. [CrossRef]

17. Becker, B.; Gerhart, B. The impact of human resource management on organizational performance: Progress and prospects. Acad. Manag. J. 1996, 39, 779-801.

18. Roscoe, S.; Subramanian, N.; Jabbour, C.J.; Chong, T. Green human resource management and the enablers of green organizational culture: Enhancing a firm's environmental performance for sustainable development. Bus. Strategy Environ. 2019, 28, 737-749. [CrossRef]

19. Melnyk, S.A.; Sroufe, R.; Calantone, R.J. Assessing the impact of environmental management systems on corporate and environmental performance. J. Oper. Manag. 2003, 21, 329-351. [CrossRef]

20. Sobaih, A.E.E. Human resource management in hospitality firms in Egypt: Does size matter? Tour. Hosp. Res. 2018, 18, 38-48. [CrossRef]

21. DuBois, C.L.; Dubois, D.A. Strategic HRM as social design for environmental sustainability in organization. Hum. Resour. Manag. J. 2012, 51, 799-826. [CrossRef]

22. Daily, B.F.; Bishop, J.W.; Massoud, J.A. The role of training and empowerment in environmental performance. Int. J. Oper. Prod. Manag. 2012, 32, 631-647. [CrossRef]

23. Thomas, R.; Shaw, G.; Page, S.J. Understanding small firms in tourism: A perspective on research trends and challenges. Tour. Manag. 2011, 32, 963-976. [CrossRef]

24. Ibeh, K.; Brock, J.K.-U.; Zhou, Y.J. The drop and collect survey among industrial populations: Theory and empirical evidence. Ind. Mark. Manag. 2004, 33, 155-165. [CrossRef]

25. Chiou, T.Y.; Chan, H.K.; Lettice, F.; Chung, S.H. The influence of greening the suppliers and green innovation on environmental performance and competitive advantage in Taiwan. Transp. Res. Part E Logist. Transp. Rev. 2011, 47, 822-836. [CrossRef]

26. Shen, J.; Benson, J. When CSR is a social norm: How socially responsible human resource management affects employee work behavior. J. Manag. 2016, 42, 1723-1746. [CrossRef]

27. Williams, L.J.; Anderson, S.E. Job satisfaction and organizational commitment as predictors of organizational citizenship and in-role behaviors. J. Manag. 1991, 17, 601-617. [CrossRef]

28. Frese, M.; Fay, D.; Hilburger, T.; Leng, K.; Tag, A. The concept of personal initiative: Operationalization, reliability and validity in two German samples. J. Occup. Organ. Psychol. 1997, 70, 139-161. [CrossRef]

29. Yong, J.Y.; Yusliza, M.Y.; Fawehinmi, O.O. Green human resource management: A systematic literature review from 2007 to 2019. Benchmarking 2019, 27, 2005-2027. [CrossRef]

30. Hair, J.; Black, W.; Babin, B.; Anderson, R. Multivariate Data Analysis, 7th ed.; Pearson: Harlow, UK, 2014.

31. Tabachnick, B.; Fidell, L. Using Multivariate Statistics, 5th ed.; Pearson: New York, NY, USA, 2007. 
32. Armstrong, J.S.; Overton, T.S. Estimating nonresponse bias in mail surveys. J. Mark. Res. 1977, 14, 396-402. [CrossRef]

33. Podsakoff, P.M.; MacKenzie, S.B.; Podsakoff, N.P. Sources of Method Bias in Social Science Research and Recommendations on How to Control It. Annu. Rev. Psychol. 2012, 63, 539-569. [CrossRef] [PubMed]

34. Bryman, A.; Cramer, D. Quantitative Data Analysis with IBM SPSS 17, 18E 19: A Guide for Social Scientists; Routledge: Abingdon, UK, 2012.

35. Anderson, J.C.; Gerbing, D.W. Structural equation modeling in practice: A review and recommended two-step approach. Psychol. Bull. 1988, 103, 411. [CrossRef]

36. Fornell, C.; Larcker, D.F. Structural equation models with unobservable variables and measurement error: Algebra and statistics. J. Mark. Res. 1981, 18, 1-22. [CrossRef]

37. Kelloway, E.K. Structural equation modelling in perspective. J. Organ. Behav. 1995, 16, 215-224. [CrossRef]

38. Sobaih, A.E.; Coleman, P.; Ritchie, C.; Jones, E. Part-time restaurant employee perceptions of management practices: An empirical investigation. Serv. Ind. J. 2011, 31, 1749-1768. [CrossRef]

39. Sobaih, A.E. The Management of Part-Time Employees in the Restaurant Industry: A Case Study of the UK Restaurant Sector; Lap Lambert Academic Publishing: Saarbrücken, Germany, 2011.

40. Sobaih, A.E.E. Half job-half training? Management perceptions of part-time employee training in the hospitality industry. J. Hum. Resour. Hosp. Tour. 2011, 10, 400-420. [CrossRef]

41. Augustyn, M.M.; Elshaer, I.A.; Akamavi, R.K. Competing models of quality management and financial performance improvement. Serv. Ind. J. 2019, 1-29. [CrossRef]

42. Sobaih, A.E.E.; Elshaer, I.; Hasanein, A.M.; Abdelaziz, A.S. Responses to COVID-19: The role of performance in the relationship between small hospitality enterprises' resilience and sustainable tourism development. Int. J. Hosp. Manag. 2021, $94,102824$. [CrossRef]

43. Morgan, R.M.; Hunt, S.D. The commitment-trust theory of relationship marketing. J. Mark. 1994, 58, 20-38. [CrossRef] 